\title{
Modern Trend of Country Made /Improvised Pistols Used in the Capital of India
}

\author{
Waghmare NP*, Suresh R, Puri P,Varshney KC, Anand V, Kompal and Anubha Lal \\ Forensic Science Laboratory, NCT of Delhi, Madhuban Chowk, Sector-14, Delhi-110085, India
}

\begin{abstract}
Now a days crimes relating to firearms and ammunition have dramatically increased in northern part of India. It has been observed that Country made pistols of $8 \mathrm{~mm} / .315$ " bore; Improvised pistols of $7.65 \mathrm{~mm} / 9 \mathrm{~mm}$ calibre, $.32 " / .38$ " calibre are randomly used by criminals in Delhi and NCR regions. On the basis of crime cases received in the Forensic Science Laboratory for examination, the smooth bore illegal country made firearms chambered for pistol, revolver and rifle cartridges are very often encountered in criminal cases all over India and other developing countries. The possibility of identifying types of smooth bore firearms of country made and improvised pistols has been studied.
\end{abstract}

On analysis of crime cases received for forensic examination, it has been found that $75 \%$ crimes are committing by $8 \mathrm{~mm} / .315$ " calibre by country made pistols, $20 \%$ by $7.65 \mathrm{~mm}$ calibre/bore improvised pistols and remaining $5 \%$ crime by other firearms like 12 bore country made pistol, .32"/.38" calibre/bore improvised pistols.

In present study, firearms details relating to length of barrel, total length of firearms, internal diameter of barrel at muzzle end and breech end have been studied in view of forensic significance and may be useful for Forensic scientists, Law Enforcement Agencies, Police Officers and Judicial Officers etc.

Keywords: Country made pistol; Improvised pistol; Ammunition; Firearm details; Barrel length; Muzzle diameter.

\section{Introduction}

Criminals, docoits, terrorists and antisocial elements in India use wide variety of firearms and their ammunition. Firearms are of wide range starting from ordinary shotgun to sophisticated military weapons, shotguns/hunting weapons as well as improvised / country made firearms. Shotguns including both breechloader and muzzle loaders, pipe guns are most popular among the criminal and antisocial elements. 12 bore, $8 \mathrm{~mm}$ and $7.65 \mathrm{~mm}$ cartridges are popular because of their easy availability through open licence arms and ammunition

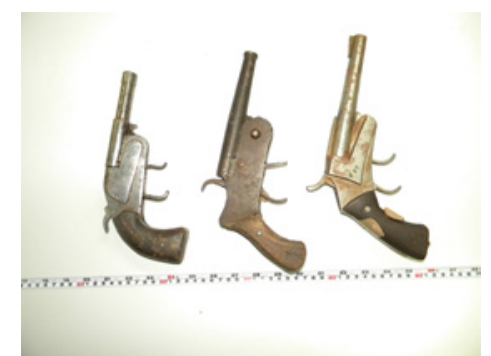

Figure 1: Country made pistols of $8 \mathrm{~mm} / .315$ " calibre (without trigger guard).

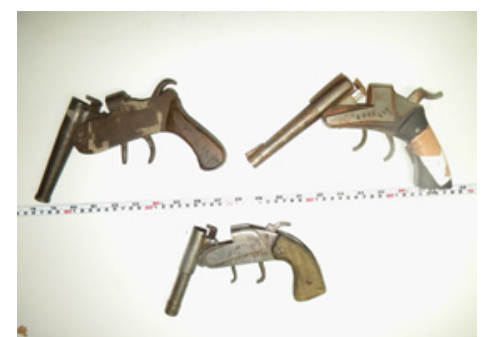

Figure 2: Country made pistols in open condition.

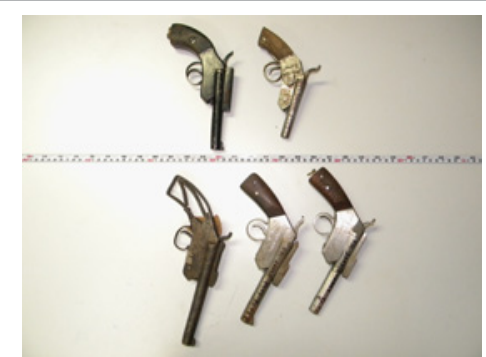

Figure 3: Country made pistols with trigger guard.

stores. Pipe guns or country made guns are frequently assembled from cheap steel pipes by antisocial persons.

The bore early type of small arms had smooth surface. The projectile consisted of a lead ball, and the powder charge as well as the projectiles were introduced into the chamber at the breech from the muzzle end of the bore, hence the name muzzle loader.

\section{Materials and Methods}

In the present systematic study, country made pistols of $8 \mathrm{~mm} / .315$ ” calibre, improvised pistols of $7.65 \mathrm{~mm}, 9 \mathrm{~mm}, .32$ " and .38 " calibre which

*Corresponding author: Waghmare NP, Forensic Science Laboratory NCT of Delhi, Madhuban Chowk, Sector-14, Delhi-110085, India, E-mail: npwaghmare@rediffmail.com

Received February 23, 2012; Accepted March 26, 2012; Published March 28 , 2012

Citation: Waghmare NP, Suresh R, Puri P, Varshney KC, Anand V, et al. (2012) Modern Trend of Country Made /Improvised Pistols Used in the Capital of India. J Forensic Res S1:003. doi:10.4172/2157-7145.S1-003

Copyright: $\odot 2012$ Waghmare NP, et al. This is an open-access article distributed under the terms of the Creative Commons Attribution License, which permits unrestricted use, distribution, and reproduction in any medium, provided the original author and source are credited. 
were received for crime examination in Delhi and used to create a data base .Scientific analysis of country made pistols of $8 \mathrm{~mm} / .315$ " bore and Improvised pistols of $7.65 \mathrm{~mm}$ bore have been studied. Comparative study of physical parameters of country made pistols and improvised pistol were done in the laboratory. Overall length, barrel length and the internal diameter of barrel at muzzle ends were measured and compared among each other.

Measurement of 80 samples data each of barrel length, total length of firearms, internal diameter of barrel at muzzle and breech end were taken for the study. They were measured by electronic venire calliper

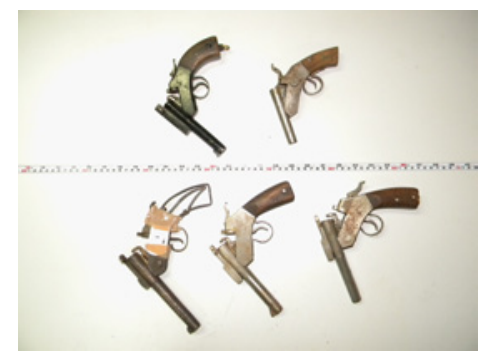

Figure 4: Country made pistols in open condition.

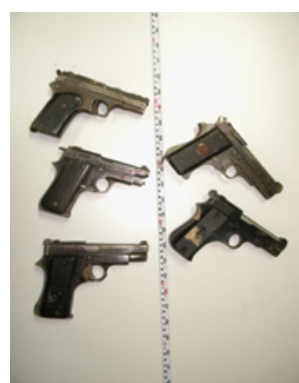

Figure 5: Improvised pistols of $7.65 \mathrm{~mm}$ calibre.

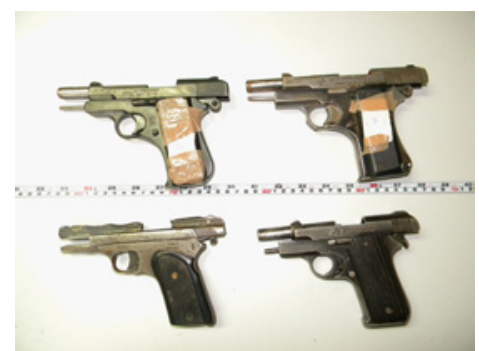

Figure 6: Improvised pistols with barrel lock condition.

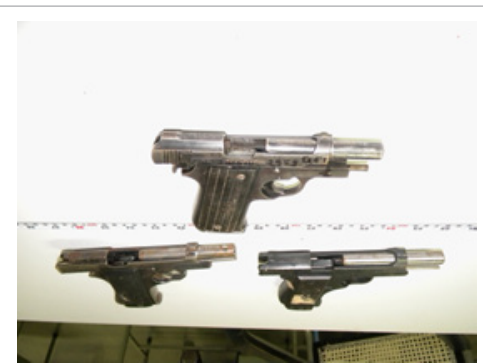

Figure 7: Improvised pistols with barrel lock above side.

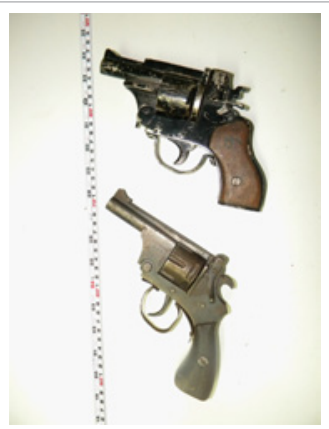

Figure 8: Country made revolver of .38" calibre.

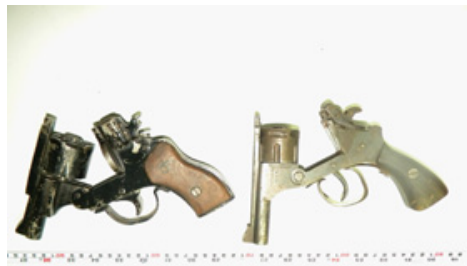

Figure 9: Country made revolver in open condition Shows a cylinder

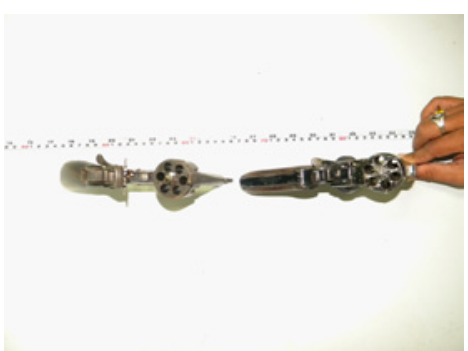

Figure 10: Country made revolver shows a cylinder with empty chambers.

made by Mitutoyo, Japan and data was statistically analysed. Details are given in table $1,2,3,4 \& 5$. The difference between country made and improvised pistols is given in table 6. Country made pistols of $8 \mathrm{~mm} / .315$ " bore, improvised pistols of $7.65 \mathrm{~mm}$ calibre and other bores firearms used Delhi \& NCR in the commission of crime. Detailed photographs of various countries made pistols and an improvised pistol were taken and given in Figure 1 to 10.

\section{Result and Discussion}

In country made pistols, length of barrel of $8 \mathrm{~mm} / .315$ " and 12 bore are $112 \mathrm{~mm}$ to $212 \mathrm{~mm}$ (approx.) and $52 \mathrm{~mm}$ to $65 \mathrm{~mm}$ (approx.) respectively, Improvised revolver of .32" bore is $75.5 \mathrm{~mm}$ to $79.17 \mathrm{~mm}$ (approx)., country made pistol of .303" bore $113 \mathrm{~mm}$ to $135 \mathrm{~mm}$ (approx.) and country made revolver of .32" bore is $76 \mathrm{~mm}$ to $110 \mathrm{~mm}$ (approx.).

It has also been observed that marksmanship and material used for country made and improvised firearms is crude steel which is easily available in commercial market. These firearms are not having any standard specifications and calibrations.

After test firing, it is observed that all fired cartridge cases were bulged and made cylindrical in shaped in country made pistols of 
Citation: Waghmare NP, Suresh R, Puri P, Varshney KC, Anand V, et al. (2012) Modern Trend of Country Made /Improvised Pistols Used in the Capital of India. J Forensic Res S1:003. doi:10.4172/2157-7145.S1-003

Page 3 of 7

\begin{tabular}{|c|c|c|c|c|}
\hline \multirow[t]{60}{*}{ Country made pistol (8mm) } & $\begin{array}{l}\text { Barrel length } \\
\text { (in } \mathrm{mm} \text { ) }\end{array}$ & $\begin{array}{l}\text { Total length } \\
\text { (in } \mathrm{mm} \text { ) }\end{array}$ & $\begin{array}{l}\text { Breech diameter } \\
\text { (in } \mathrm{mm} \text { ) }\end{array}$ & $\begin{array}{l}\text { Muzzle diameter } \\
\text { (in } \mathrm{mm} \text { ) }\end{array}$ \\
\hline & 112 & 240 & 13.54 & 8.67 \\
\hline & 110 & 230 & 12.62 & 8.53 \\
\hline & 135 & 262 & 12.74 & 8.91 \\
\hline & 102.73 & 230 & 12.91 & 8.17 \\
\hline & 156 & 249 & 13.44 & 8.74 \\
\hline & 109 & 200 & 12.68 & 9.44 \\
\hline & 125 & 270 & 12.62 & 8.54 \\
\hline & 190 & 300 & 12.67 & 9.49 \\
\hline & 139 & 245 & 12.62 & 8.05 \\
\hline & 152 & 250 & 12.73 & 9.14 \\
\hline & 135 & 252 & 12.10 & 9.60 \\
\hline & 100 & 220 & 12.68 & 8.62 \\
\hline & 177 & 310 & 12.85 & 8.95 \\
\hline & 212 & 350 & 12.10 & 8.39 \\
\hline & 111 & 230 & 12.71 & 9.38 \\
\hline & 127.05 & 260 & 12.35 & 9.00 \\
\hline & 127 & 237 & 12.55 & 8.98 \\
\hline & 107.36 & 230 & 12.14 & 8.45 \\
\hline & 130 & 240 & 12.84 & 8.60 \\
\hline & 151 & 260 & 12.73 & 8.58 \\
\hline & 128.63 & 260 & 12.60 & 9.28 \\
\hline & 152 & 270 & 12.73 & 8.32 \\
\hline & 143.55 & 250 & 12.81 & 7.97 \\
\hline & 133.42 & 285 & 12.63 & 9.47 \\
\hline & 171 & 297 & 12.85 & 9.20 \\
\hline & 165 & 293 & 13.40 & 9.57 \\
\hline & 165 & 270 & 13.04 & 11.24 \\
\hline & 112 & 235 & 14.77 & 9.31 \\
\hline & 131 & 235 & 12.5 & 8.77 \\
\hline & 130.98 & 235 & 12.54 & 8.53 \\
\hline & 110 & 225 & 12.32 & 8.72 \\
\hline & 118.20 & 225 & 15.16 & 8.29 \\
\hline & 157 & 268 & 12.71 & 7.77 \\
\hline & 135.06 & 250 & 12.46 & 8.11 \\
\hline & 144 & 260 & 13.05 & 8.75 \\
\hline & 105 & 215 & 12.80 & 8.78 \\
\hline & 125.68 & 238 & 14.05 & 9.34 \\
\hline & 158 & 280 & 13.08 & 8.38 \\
\hline & 195 & 330 & 13.78 & 10.10 \\
\hline & 150 & 270 & 12.40 & 8.52 \\
\hline & 183 & 300 & 13.72 & 12.85 \\
\hline & 131.07 & 220 & 12.66 & 8.29 \\
\hline & 155 & 270 & 12.66 & 10.57 \\
\hline & 181 & 300 & 12.10 & 12.08 \\
\hline & 152 & 252 & 12.36 & 8.58 \\
\hline & 114.94 & 240 & 12.24 & 8.80 \\
\hline & 130 & 225 & 12.58 & 8.16 \\
\hline & 170 & 300 & 12.77 & 8.61 \\
\hline & 140 & 250 & 12.58 & 9.65 \\
\hline & 134.20 & 250 & 13.40 & 8.88 \\
\hline & 97.33 & 215 & 12.47 & 8.70 \\
\hline & 145.45 & 275 & 12.08 & 8.51 \\
\hline & 182 & 284 & 13.92 & 8.96 \\
\hline & 153 & 293 & 12.06 & 9.45 \\
\hline & 127.28 & 245 & 13.84 & 7.83 \\
\hline & 150.82 & 280 & 12.46 & 8.76 \\
\hline & 163 & 300 & 14.66 & 8.88 \\
\hline & 145.39 & 272 & 12.65 & 8.34 \\
\hline & 135.75 & 235 & 12.79 & 8.76 \\
\hline
\end{tabular}


Citation: Waghmare NP, Suresh R, Puri P, Varshney KC, Anand V, et al. (2012) Modern Trend of Country Made /Improvised Pistols Used in the Capital of India. J Forensic Res S1:003. doi:10.4172/2157-7145.S1-003

Page 4 of 7

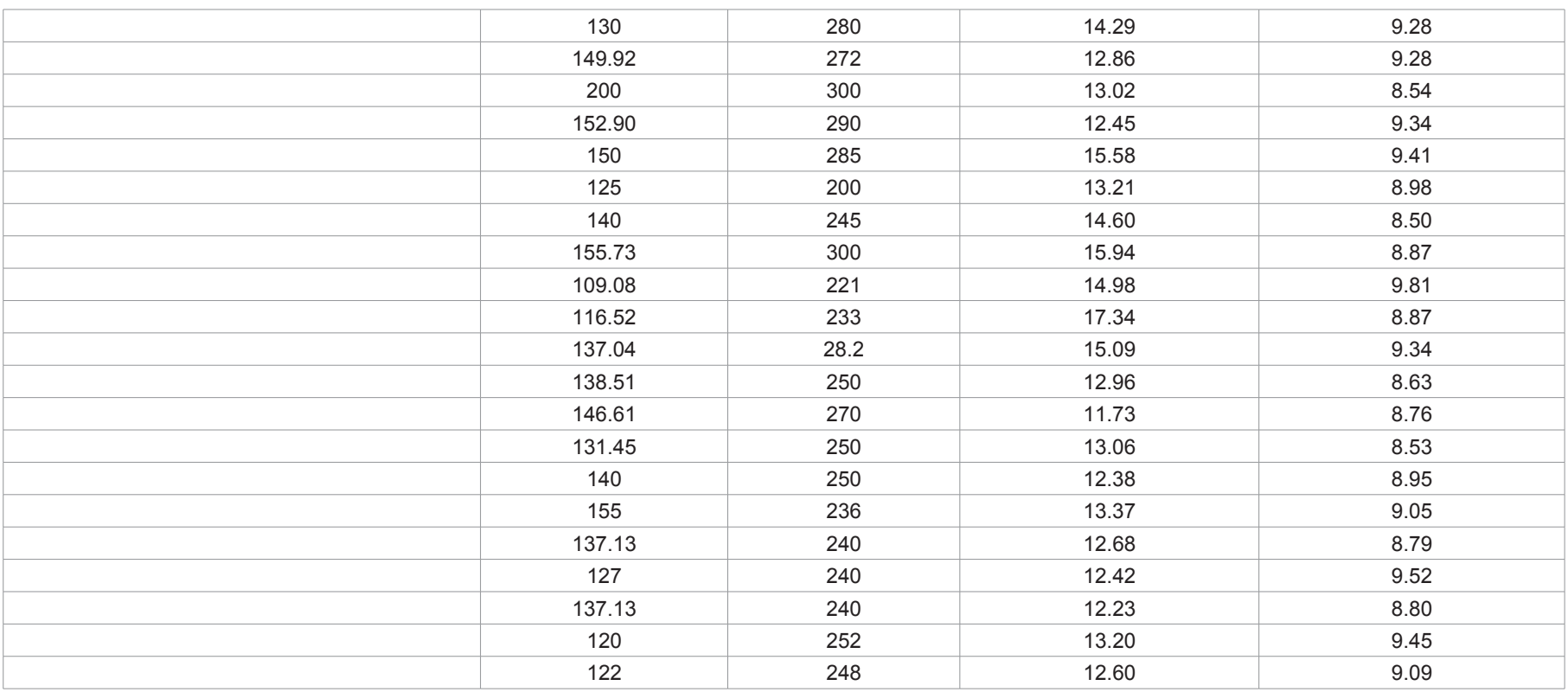

Table 1: Technical details of country made pistols of $8 \mathrm{~mm} / .315$ " bore: All country made firearms are smooth bore.

\begin{tabular}{|c|c|c|c|c|c|c|}
\hline $\begin{array}{l}\text { Improvised pistol } \\
\quad(7.65 \mathrm{~mm})\end{array}$ & $\begin{array}{l}\text { Barrel length } \\
\quad \text { (in } \mathrm{mm} \text { ) }\end{array}$ & $\begin{array}{l}\text { Total length } \\
\text { (in } \mathrm{mm} \text { ) }\end{array}$ & $\begin{array}{l}\text { Muzzle diameter } \\
\quad \text { (in } \mathrm{mm} \text { ) }\end{array}$ & $\begin{array}{l}\text { Smooth bore or Rifled } \\
\text { firearms }\end{array}$ & $\begin{array}{l}\text { No. of lands and } \\
\text { grooves }\end{array}$ & $\begin{array}{l}\text { Direction of rifling } \\
\text { Left hand side (LHS)/ } \\
\text { Right hand side (RHS) }\end{array}$ \\
\hline & 190 & 990 & 7.76 & Rifled & 6 & LHS \\
\hline & 100.89 & 200 & 7.50 & Rifled & 6 & LHS \\
\hline & 99.32 & 195 & 8.04 & Rifled & 6 & LHS \\
\hline & 89 & 185 & 7.75 & Rifled & 6 & LHS \\
\hline & 96.31 & 190 & 7.43 & Rifled & 5 & RHS \\
\hline & 89.30 & 200 & 7.45 & Rifled & 6 & RHS \\
\hline & 102.04 & 200 & 7.55 & Rifled & 6 & LHS \\
\hline & 100.01 & 205 & 7.52 & Rifled & 5 & RHS \\
\hline & 101.90 & 195 & 7.92 & Rifled & 5 & RHS \\
\hline & 99.05 & 195 & 7.83 & Rifled & 8 & RHS \\
\hline & 100 & 196 & 8.08 & Rifled & 6 & LHS \\
\hline & 98.96 & 195 & 7.68 & Rifled & 4 & LHS \\
\hline & 94 & 185 & 8.07 & Smooth & 6 & LHS \\
\hline & 97 & 192 & 7.98 & Rifled & 6 & RHS \\
\hline & 101.18 & 198 & 7.26 & Rifled & 6 & RHS \\
\hline & 102.81 & 200 & 8.16 & Rifled & 6 & LHS \\
\hline & 101.60 & 190 & 7.65 & Rifled & 6 & RHS \\
\hline & 92.04 & 190 & 7.82 & Rifled & 5 & LHS \\
\hline & 100.62 & 192 & 7.70 & Rifled & 6 & RHS \\
\hline & 109.64 & 210 & 7.98 & Rifled & 4 & RHS \\
\hline & 97.15 & 200 & 7.86 & Rifled & 5 & RHS \\
\hline & 92 & 200 & 7.97 & Rifled & 6 & RHS \\
\hline & 78 & 170 & 8.21 & Rifled & 6 & LHS \\
\hline & 99 & 195 & 7.14 & Rifled & 6 & RHS \\
\hline & 107 & 206 & 8.01 & Rifled & 6 & LHS \\
\hline & 108 & 204 & 7.95 & Rifled & 6 & LHS \\
\hline & 107 & 197 & 7.00 & Rifled & 6 & LHS \\
\hline & 100 & 200 & 7.82 & Rifled & 6 & RHS \\
\hline & 96 & 193 & 8.12 & Rifled & 4 & RHS \\
\hline & 92 & 193 & 8.00 & Rifled & 4 & RHS \\
\hline & 100 & 200 & 7.60 & Smooth & 4 & RHS \\
\hline & 100 & 192 & 8.10 & Rifled & 5 & RHS \\
\hline & 100 & 210 & 7.92 & Rifled & 6 & LHS \\
\hline & 100 & 197 & 7.57 & Rifled & 6 & LHS \\
\hline & 95 & 195 & 7.98 & Rifled & 6 & LHS \\
\hline
\end{tabular}


Citation: Waghmare NP, Suresh R, Puri P, Varshney KC, Anand V, et al. (2012) Modern Trend of Country Made /Improvised Pistols Used in the Capital of India. J Forensic Res S1:003. doi:10.4172/2157-7145.S1-003

Page 5 of 7

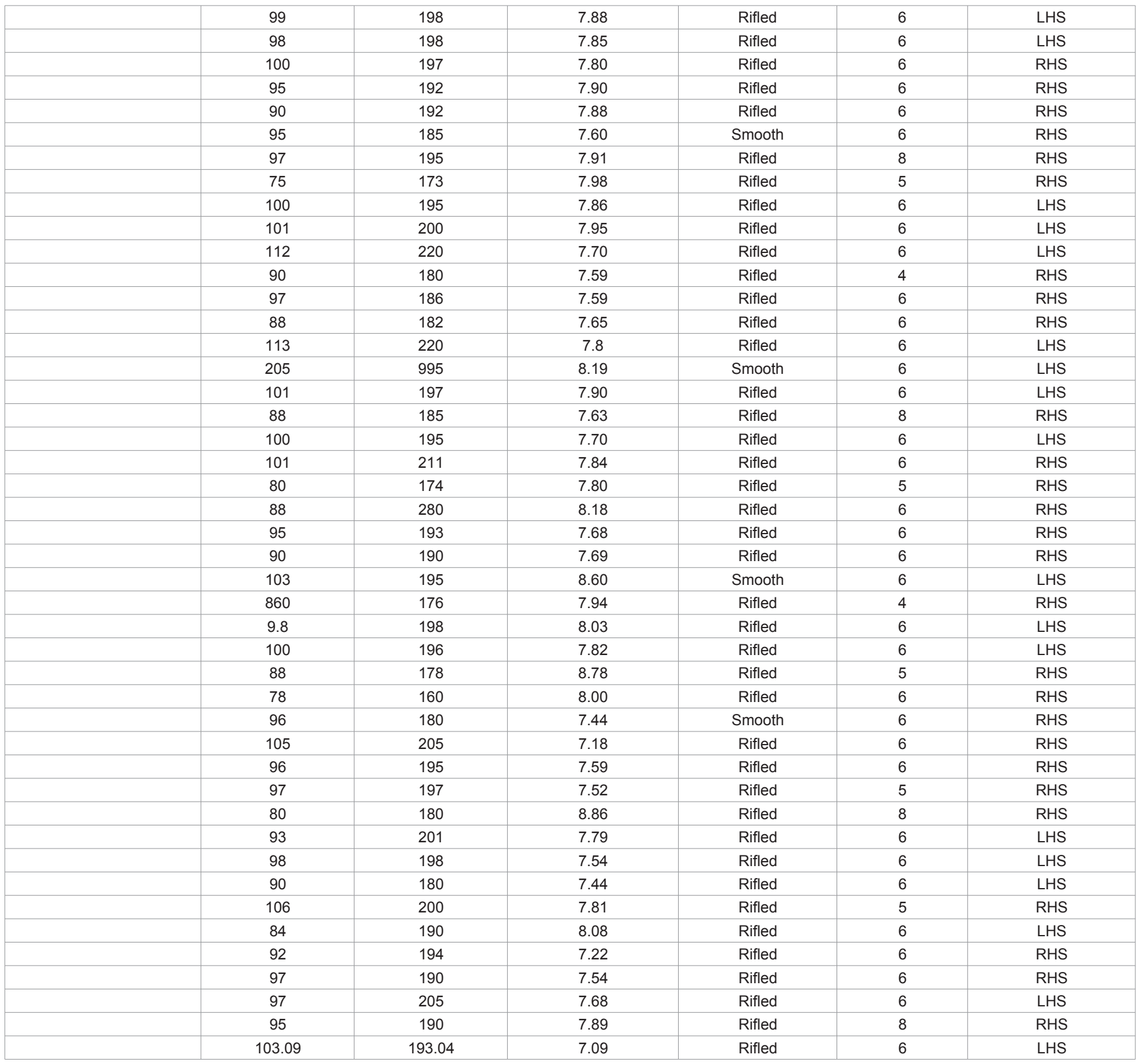

Table 2: Technical details of Improvised pistols of $7.65 \mathrm{~mm}$ bore.

$8 \mathrm{~mm} / .315$ ” bore while in improvised pistols, all fired cartridges cases were protruded and bulged. Almost all improvised pistols of $7.65 \mathrm{~mm}$ and $9 \mathrm{~mm}$ bore were having fake registration number like 111, 777, AUTOMATIC PISTOL, MADE IN USA/ITALY embossed on the body and other portion of barrels. In most of the cases, spelling mistakes were also found in many improvised pistols. On the other hand, .315 along with the year of manufacturing were also encrypted on country made pistol body portion of $8 \mathrm{~mm} / .315$ " bore in few cases [1-5].

Effective Range of Country made Pistol and Improvised Pistols

It is expected for ballistics experts to have an idea of the effective ranges of various types of firearms encountered in crimes. The effective range of a firearm may be defined as the range which a man size target can be hit with certainty. Generally Country made/improvised firearms have capacity to kill a person depending upon range of firing, velocity loss into the target and last but not least the portion of body where the projectile hits. These country made /improvised firearms are crudely made from cheap steel tubes, sanitary/water pipes etc. It is a fact the criminals improved a firearms to fire the regular cartridges available with them in local market [1-5].

The $8 \mathrm{~mm} / .315$ " and $7.65 \mathrm{~mm}$ bore ammunition are available in open licence shops. In Delhi, NCR and neighbouring States like UP, Haryana \& Rajasthan, Hence, criminals are mostly using country made pistols of $8 \mathrm{~mm} / .315$ " bore and improvised pistol of $7.65 \mathrm{~mm}$ bore. Some of these country made/improvised firearms are so well made that 
Citation: Waghmare NP, Suresh R, Puri P, Varshney KC, Anand V, et al. (2012) Modern Trend of Country Made /Improvised Pistols Used in the Capital of India. J Forensic Res S1:003. doi:10.4172/2157-7145.S1-003

Page 6 of 7

\begin{tabular}{|c|c|c|c|c|c|c|}
\hline $\begin{array}{l}\text { Improvised pistol } \\
(9 \mathrm{~mm})\end{array}$ & $\begin{array}{l}\text { Barrel length } \\
\text { (in mm) }\end{array}$ & $\begin{array}{l}\text { Total length } \\
\text { (in } \mathrm{mm} \text { ) }\end{array}$ & $\begin{array}{l}\text { Muzzle diameter } \\
\text { (in } \mathrm{mm} \text { ) }\end{array}$ & $\begin{array}{l}\text { Smooth bore/rifled } \\
\text { firearms }\end{array}$ & $\begin{array}{l}\text { No. of lands and } \\
\text { grooves }\end{array}$ & $\begin{array}{c}\text { Direction of rifling } \\
\text { Left hand side (LHS)/ } \\
\text { Right hand side (RHS) }\end{array}$ \\
\hline & 109.09 & 210 & 9.52 & Rifled & 4 & RHS \\
\hline & 115 & 217 & 8.76 & Smooth bore & - & - \\
\hline & 109.89 & 214 & 8.86 & Rifled & 6 & RHS \\
\hline & 111.02 & 225 & 9.39 & Smooth bore & - & - \\
\hline & 116.67 & 225 & 8.81 & Rifled & 6 & RHS \\
\hline & 118 & 210 & 8.54 & Rifled & 8 & RHS \\
\hline & 116 & 220 & 8.93 & Smooth bore & - & - \\
\hline & 120 & 225 & 9.03 & Smooth bore & - & - \\
\hline & 107 & 207 & 9.61 & Smooth bore & - & - \\
\hline & 103 & 220 & 9.06 & Rifled & 6 & LHS \\
\hline & 111 & 221 & 7.41 & Rifled & 6 & LHS \\
\hline & 110 & 210 & 8.68 & Smooth bore & - & - \\
\hline & 121 & 218 & 8.82 & Smooth bore & - & - \\
\hline & 99 & 202 & 9.09 & Smooth bore & - & - \\
\hline & 116 & 225 & 8.82 & Rifled & 6 & LHS \\
\hline & 120 & 219 & 8.91 & Rifled & 6 & RHS \\
\hline & 110 & 220 & 9.15 & Smooth bore & - & - \\
\hline & 112 & 214 & 8.89 & Smooth bore & - & - \\
\hline 19) & 114 & 210 & 8.76 & Rifled & 6 & LHS \\
\hline 20) & 112 & 207 & 9.12 & Rifled & 6 & RHS \\
\hline
\end{tabular}

Table 3: Technical details of improvised pistols of $9 \mathrm{~mm}$ calibre.

\begin{tabular}{|c|c|c|c|c|}
\hline Country made pistol (12 Bore) & Barrel length (in mm) & Total length (in mm) & Muzzle diameter (in mm) & Smooth bore or Rifled \\
\hline & 151 & 300 & 16.66 & Smooth bore \\
\hline & 173 & 302 & 19.46 & Smooth bore \\
\hline & 282 & 430 & 16.70 & Smooth bore \\
\hline & 175 & 320 & 19.29 & Smooth bore \\
\hline & 182 & 300 & 20.04 & Smooth bore \\
\hline & 180 & 315 & 18.83 & Smooth bore \\
\hline & 194 & 338 & 18.08 & Smooth bore \\
\hline & 136 & 276 & 21.34 & Smooth bore \\
\hline & 160 & 280 & 17.45 & Smooth bore \\
\hline & 151 & 280 & 16.32 & Smooth bore \\
\hline & 149 & 281 & 18.25 & Smooth bore \\
\hline & 160 & 270 & 19.25 & Smooth bore \\
\hline & 176 & 285 & 18.07 & Smooth bore \\
\hline & 160 & 290 & 22.03 & Smooth bore \\
\hline & 153 & 290 & 17.62 & Smooth bore \\
\hline & 114 & 251 & 17.59 & Smooth bore \\
\hline & 170 & 320 & 17.69 & Smooth bore \\
\hline & 160 & 307 & 18.37 & Smooth bore \\
\hline & 155 & 290 & 18.20 & Smooth bore \\
\hline & 160 & 290 & 18.42 & Smooth bore \\
\hline
\end{tabular}

Table 4: Technical details of country made pistols of 12 bore.

\begin{tabular}{|c|c|c|c|c|c|c|}
\hline $\begin{array}{l}\text { Country made revolver } \\
\qquad(.32 \text { ") }\end{array}$ & $\begin{array}{l}\text { Barrel length } \\
\quad \text { (in } \mathrm{mm} \text { ) }\end{array}$ & $\begin{array}{l}\text { Total length } \\
\text { (in } \mathrm{mm} \text { ) }\end{array}$ & $\begin{array}{l}\text { Muzzle diameter } \\
\text { (in } \mathrm{mm} \text { ) }\end{array}$ & $\begin{array}{l}\text { Smooth bore or Rifled } \\
\text { firearms }\end{array}$ & $\begin{array}{l}\text { No. of lands and } \\
\text { grooves }\end{array}$ & $\begin{array}{c}\text { Direction of rifling } \\
\text { Left hand side (LHS)/ } \\
\text { Right hand side (RHS) }\end{array}$ \\
\hline 1) & 76 & 223 & 7.90 & Smooth bore & - & - \\
\hline 2) & 108 & 219 & 7.66 & Smooth bore & - & - \\
\hline 3) & 60 & 220 & 7.87 & Smooth bore & - & - \\
\hline 4) & 80 & 207 & 8.58 & Smooth bore & - & - \\
\hline 5) & 60 & 230 & 8.60 & Smooth bore & - & - \\
\hline 6) & 52 & 199 & 8.60 & Rifled & 6 & LHS \\
\hline 7) & 75 & 230 & 7.65 & Rifled & 6 & LHS \\
\hline 8) & 119 & 220 & 7.84 & Rifled & 6 & RHS \\
\hline 9) & 75 & 222 & 7.74 & Smooth bore & - & - \\
\hline 10) & 64.46 & 230 & 8.23 & Rifled & 6 & RHS \\
\hline
\end{tabular}

Table 5: Technical details of country made revolvers of .32" bore. 
Citation: Waghmare NP, Suresh R, Puri P, Varshney KC, Anand V, et al. (2012) Modern Trend of Country Made /Improvised Pistols Used in the Capital of India. J Forensic Res S1:003. doi:10.4172/2157-7145.S1-003

\begin{tabular}{|c|c|c|}
\hline S.No. & Country made pistols & Improvised pistols \\
\hline 1. & $\begin{array}{l}\text { Country made pistols are manufactured by ordinary blacksmith without any } \\
\text { standard specification or materials used. }\end{array}$ & $\begin{array}{l}\text { Improvised pistols are manufactured locally with proper knowledge of } \\
\text { standard weapons and these are the copy (imitation) of standard caliber } \\
\text { pistols. }\end{array}$ \\
\hline 2. & $\begin{array}{l}\text { Different types of ammunition can be fired from country made pistols like } \\
8 \mathrm{~mm} / .315 ", .303 \text { " and } 7.62 \times 51 \mathrm{~mm} \text { caliber (using suitable adopter). }\end{array}$ & $\begin{array}{l}\text { It can be used with proper caliber ammunition for which it has been } \\
\text { made. }\end{array}$ \\
\hline 3. & Generally, these are single shot hammer action pistols without magazine. & Generally, these are semi-automatic pistols with magazine. \\
\hline 4. & Only one cartridge can be fired at a time. Next cartridge can be loaded manually. & $\begin{array}{l}\text { Number of cartridges loaded in magazine (upto } 8 \text { to 10) can be fired } \\
\text { at a time. }\end{array}$ \\
\hline 5. & Generally, rimmed cartridges are used to fire. & Generally, only rimless or semi-rimless cartridges can be fired. \\
\hline 6. & Generally, these are smooth bore firearms. & Generally, these are rifled as well as smooth bore firearms. \\
\hline 7. & $\begin{array}{l}\text { No safety mechanism like safety catch are found present in country made } \\
\text { pistols. }\end{array}$ & Generally, a safety notch is present in improvised pistols. \\
\hline 8. & The firing pin present in country made pistols can be easily replaced. & The firing pin present in improvised pistols are difficult to replace. \\
\hline 9. & $\begin{array}{l}\text { The barrels of country made pistols are generally manufactured by iron pipe, } \\
\text { sanitation pipe etc. }\end{array}$ & $\begin{array}{l}\text { The barrels of improvised pistols are manufactured with the help of } \\
\text { machine like lath machine etc. }\end{array}$ \\
\hline 10. & The shape of country made pistols are not look like as standard weapon. & The shape of improvised pistols are look like as standard weapon. \\
\hline 11. & The barrel catch lever is present for opening and closing the barrel. & In this case magazine catch is present in improvised pistols. \\
\hline
\end{tabular}

Table 6: The difference between country made and improvised pistols.

they can be mistaken to be a factory made on a cursory look. It is also observed that, the barrels of country made pistol are usually, smooth bored and rifling's are made in an improvised pistols of $7.65 \mathrm{~mm}, 9 \mathrm{~mm}$. Sometimes these rifling are incomplete, straight in the barrel and there is no consistency in diameter of lands and grooves. Finishing of lands and grooves also not as like to standard rifling in regular firearms [6-8].

It has also been observed that muzzle velocity developed in such type of firearms usually much less than the normal velocity of the cartridge used. It has been found that internal diameter of barrel at muzzle end of an improvised pistol of $7.65 \mathrm{~mm}$ bore are found to be less than the actual diameter of standard pistol of same calibre. Here also no such standard factory parameters were applied for making muzzle diameter of barrel. It varies from $7 \mathrm{~mm}$ to $8.86 \mathrm{~mm}$ (approx.). Overall length of improvised pistols is also vary from $16.5 \mathrm{~mm}$ to $22 \mathrm{~mm}$ (approx.) and no such specific standard were adopted by 'the criminals/ illegal firearm manufacturers.

\section{Conclusion}

Average total length of country made pistols found to vary from $140.64 \mathrm{~mm}$ (approx.) and $258.08 \mathrm{~mm}$ and in Improvised pistols from $108.64 \mathrm{~mm}$ (approx.) and $214.86 \mathrm{~mm}$ (approx.). Internal diameter of barrels in country made pistols and improvised pistols at muzzle ends were found to vary from $7.79 \mathrm{~mm}$ and $8.99 \mathrm{~mm}$ (approx.) respectively.

It has also been observed that total lengths of $7.65 \mathrm{~mm}$ bore improvised pistol are different from each other and also vary from
$170 \mathrm{~mm}$ to $220 \mathrm{~mm}$ (approx). Firearm details of country made pistol and improvised pistols in this paper may be useful to Law Enforcement Agencies and Police Officers, Experts of Forensic Ballistics, Law Officers and Judicial Officers etc.

\section{Acknowledgment}

Authors are very grateful to Director, FSL, Govt. of NCT of Delhi, Madhuban Chowk, Sector 14, Rohini, Delhi-110085 for his keen interest and constant encouragement.

\section{References}

1. Burrard G (1952) The Modern shot gun. Herbert Jenkins, Landon, 2: 253-265.

2. Jauhari M (1978) Identification of firearms, ammunition and firearm injures. Printed by Manager, govt. Of India press, Nashik and published by the controller of publications, Delhi-54, India 62-68.

3. Hatcher JS (1957) Hatcher's Note Book. Stock Pole Company, Harries bergPennsylvania 511-519.

4. Hagg LC (2006) Shooting Incident Reconstruction. Elsevier 187-196.

5. Vincent JM DiMaio (1993) Gunshot Wounds: Practical aspects of firearms ballistics, and forensic techniques. Bocaraton Press, CRC 190-198.

6. Hamilton SL (2008) Forensic Ballistics: Styles of Projectiles, ABDO Publications Co. 4-10.

7. Rollings BB (2004) Ballistics. Michael Dahl Publisher, Mankato, Capstone Press 5-18.

8. Waghmare NP, Manna A, Rao MS, Sen PK (2003) Statistical analysis of impact parameters of soft nose bullet fired on windowpane. Forensic Sci Int 181-187. 